\title{
Brain Based Learning: Effects Model A-Car in Critical Thinking Skills
}

\author{
Dwiyono Hari Utomo \\ Department of Geography \\ Faculty of Social Science \\ State University of Malang \\ Corresponding email: dwiyono.hari.fis@um.ac.id
}

\begin{abstract}
The human brain has the cognitive areas that can be used to think high, and need maintenance of brain development. Brain cells of human beings from birth and forever keep possession, even grew as an adult, in line with the development of maturity. The frontal lobes are dealing with abstract reasoning and problem solving more mature and parietal lobes grow in size. Students are appropriately able to manage her brain to produce results in the form of thoughts or ideas. The ability of the student to manage his brain does not always work, even more students are silent, without ideas. In such conditions, the student needs habituation way of managing the brain through a series of learning activities. This study aimed to obtain a student response to the application of the model A-CAR on critical thinking skills. Model A-CAR has a syntax to enable the brain works. The syntax includes Activation, Confirmation, Activities, Resume. The study was designed using the experiment. Data obtained from the test are then analyzed using t-test. The results of t-test showed that the model A-CAR higher critical thinking skills acquisition results compared to direct instructional models.
\end{abstract}

Keywords-Brain based learning, model A-CAR, critical thinking

\section{INTRODUCTION}

The human brain receives sensory information comes from. Information is processed through the analysis, integration, and synthesis and summarizes the overall information is then stored in the thalamus (Sousa, 2012), (Jensen, 2011), (Reed, 2011). Brain sustainably reorganize themselves through the experience of shaping the neural circuits that will determine how the brain learns and later period (Sousa, 2012). Brain engagement process on an ongoing basis to form a critical component in the transfer of information from working memory to the long-term memory storage (Sousa, 2012) (Reed, 2011).

Learning in higher education involving the brain actively seek and find information through learning activities. Learning involves memory, both of which are neuroplastic process. Learning to relate to the conversion experience (Pinel, 2009), and the acquisition of knowledge (Gross, 2012). Storage memory after brain associated with reactivated (Pinel, 2009), and into a retention (Gross, 2012). Retention built through a logical conceptual framework and has meaning, and consolidated into long-term storage network (Sousa, 2012). The use of various strategies, approaches, models, methods, and learning media is intended to improve retention. The results of study these days is simply not acceptable and applicable for today, but it can be stored and used in the following days.

Increased retention of learning needs to be done on the student in question in the way of learning. Student learning problems seen in curiosity weakened, class discussions "hollow" without an argument, and passivity to seek and find yourself. The scheme in direct instructional student who hopes to be able to receive without searching. Proper functioning of the brain needs to be intensified in learning, because every human being can learn effective if given brain function as well as how the brain learns (Saleh, 2011). Model A-CAR (Activation, Confirmation, Activities, and Resume) pay attention to the way the brain learns that aims to improve critical thinking skills. Critical thinking be the goal of a college education (Arend, 2009), but in practice has not led to the achievement of learning critical thinking.

The application of brain-based learning in learning can improve academic achievement (Duman, 2006), achievement, attitude and retention, achievements of conceptual understanding (Saleh, 2011). Nuangchalerm and Charnsirirattana (2010), to develop a model PRADA (Preparation, Relaxation, Action, Discussion, and Application). Tompkins (2007) developed a model of IGNITE (Interval, Grouping, Novelty, interconnectedness, Technology, and Environment). Seesom (2012) developed Braise models (Brain-Gym, Rouse, Accessing Information, Implementation, Summary, and Extension). Sousa, 1995; Smith, 2003 (in Saleh, 2011) integrates the principles of brain-based learning through seven phases brain compatible instructional. The phases include: Activation, Clarify the outcomes and paint the big picture, Making a connection and develop meaning, Doing the learning activity, Application and integration / Demonstrate students understanding, Review for students retention / Closure, Preview the next topic.

Brain-based learning has been implemented within the framework of the study varied, namely experiment (Duman, 2006; Ozden, 2008; Pennington, 2010; Saleh, 2011), qualitative (Tompkins, 2007), development (Nuangchalerm and Charnsirirattana, 2010); correlation (Klinek, 2009; 
Kiedinger 2011; Ghraibeh, 2012). The research was conducted within the framework of experimental research.

\section{METHOD}

This research is a quasi-experimental with control group design. Control class by applying direct learning model, while the experimental class by applying A-CAR learning model. The population includes all students in MeteorologyClimatology courses in the second semester 2014/2015. Control class and experimental class as a research subject was determined by random. The research was conducted during one semester, and two tests, namely the Middle Exam (ME) and Final Exam (FE). The results of tests on the control class and experimental class was analyzed using t-test at the 0.05 level. See Table 1.

TABLE 1. DESIGN QUASI-EXPERIMENTAL

\begin{tabular}{|c|c|c|c|c|}
\hline \multirow{2}{*}{ Class } & \multirow{2}{*}{ Treatment } & \multicolumn{2}{|c|}{ Test } & \multirow{2}{*}{ Analysis } \\
\cline { 3 - 4 } & & ME & FE & \\
\hline control & direct learning model & $\checkmark$ & $\checkmark$ & \multirow{2}{*}{ t-test } \\
\hline experiment & A-CAR learning model & $\checkmark$ & $\checkmark$ & \\
\hline
\end{tabular}

\section{FINDING AND DISCUSSIONS}

\section{A. Brain Based Learning: A-CAR}

The human brain has the cognitive areas that can be used to think high (higher-order thinking), and the necessary maintenance of brain development (Sylwester, 1997 in Clemons, 2004). The brain learns new patterns and to creations on the pattern that has been mastered into the pattern itself. The process of recognition or scanning the pattern can occur template matching (Reed, 2011; Solso, et al. 2008) that match and complete the pattern. Students are further required to develop higher-level thinking, such as critical thinking that is more meaningful. Making of this happens if students do cognitive connections in the brain.

Learning generally involve the brain to think, but brainbased learning is characterized by the involvement of the strategy is based on principles derived from an understanding of the brain. Brain-based learning is studied according to the way the brain learns, is designed by nature to learn, and consider how the brain learns optimally (Jensen, 2011), learning approach based on the structure and function of the human brain. The human brain as an organ that has the potential for extremely high and every human being can learn effectively if given brain function as well as how the brain learns (Saleh, 2011).

Brain-based learning into the basic model of the A-CAR is procedurally activated the workings of the brain. Learning begins from the activation of the brain to activate the neuron, then be ready to do the critical thinking process. Learning planned using the syntax: Activation, Confirmation, Activities, and Resume.
Activation in the model A-CAR is the first step to enable the students. Activation is meant to stimulate memory processor system. The form of questions (Sousa, 2012) conducted a foothold cognitive activation of neurons perform his duties activate neurons that others in the elements of the brain. Functions neurons as receiver and sender information. Impulses nerve extends from the axon to the synapse releases neurotransmitter triggering receptor sites on other neurons to form the pattern of connections between neurons (Sousa, 2012), and the more connections are made, the better (Jensen, 2011).

Confirmation in the model A-CAR is intended to convey the purpose of learning, but students can propose other purposes, then becomes a shared commitment. Confirmation of the objectives need to be written down and shared commitment, because the goal is an important aspect of learning (Jensen, 2011). Placement learning objectives prior learning activities to provide direction to the concentration, the outpouring of concern (Reed, 2011), and improve performance (Jensen, 2011). Interest can also be a challenge that must be faced, because learning is enhanced by challenge and inhibited by threat (Caine and Caine, 1990).

Activities in the model A-CAR is at the core of learning in the form of learning activities. Activities can be read (text, graphics, tables), interpret images, perform internet links, tasks, answer questions, make inquiries, and make notes. Activities to learn to build a dynamic brain work supported by the app to get the concept of the usefulness of the concept. Resume to be a step late model A-CAR to give the effect of strengthening the concept, retention, and facilitate dialing memory.

\section{B. Critical Thinking}

Critical thinking is a way of thinking to decide based on the argument (Onions, 2009 in Kalelioğlu, et al. 2014). Educate critical thinking skills, must engage students in discussion and reasoning, looking for evidence to conclusions, make decisions or find solutions (Huang, et al. 2012). Various methods have been carried out not only on testing methods but have confirmed the effectiveness of the method, because the use of effective methods to encourage students pursuing a strategy of critical thinking (Arend, 2009). Critical thinking strategies that have been grown in students can be developed into a pattern of thinking. Patterns of thinking that continuously carried out in response to learning can be developed into analytical skills. Analytical skills give birth to creativity, habits reflect, and ask the various aspects of life (King, 1995).

Critical thinking is a logical consequence of brain-based learning, critical thinking involves the ability to think to respond jelly and argumentative. Critical thinking is a selfregulatory judgment which is realized through the interpretation, analysis, evaluation, and inference (Paul, et al. 2007), organized cognitive process (Cüceloglu, 1994, in Arslan, 2015). Critical thinking skills include knowledge, ability and willingness to ask and answer questions at the right 
time (Browne and Keeley, 2012), through appropriate measures, Jensen (2011) calls it a survival imperative. Critical thinking has characteristics: Asking questions, defining a problem, examining evidence, analyzing assumptions (Wade, in Arslan, 2015), interpretation, analysis, evaluation, and inference (Paul, et al. 2007), and their challenges (Brookfield, 1987, in Marrapodi, 2003).

Critical thinking skills can be taught (Jensen, 2011), therefore, critical thinking can be built through reading, writing, listening and speaking. Critical thinking can occur when faced with the choice to decide, or solve the problem, determine the kind of action that should be done in a logical way. Critical thinking skills by Fisher (2001) referred to as the ability to think on what he was thinking (thinking about thinking ones) or metacognitive.

Critical thinking requires the ability to identify problems, find solutions, understand the priority of solving the problem, using a language that is precise, clear, and unequivocal, data interpretation, find the logical relationship between propositions, draw conclusions and generalizations, reconstruct the pattern, and an accurate assessment of things certain. Thus critical thinking are conceptual, as presented by Brookfield, (1987, in Marrapodi, 2003): "Critical thinking is a process, not an outcome, manifestations of critical thinking vary According to the Contexts in the which it Occurs".

\section{Result}

Test critical thinking skills that consists of the elements contained in the critical thinking test questions. The test results critical thinking skills experimental class and control class can be seen in Figure 1. The average test results critical thinking skills experiment class and control class 4.29 and 6.02. Based on different mean, t-test result that was significant at the level $0.037<0.05$.

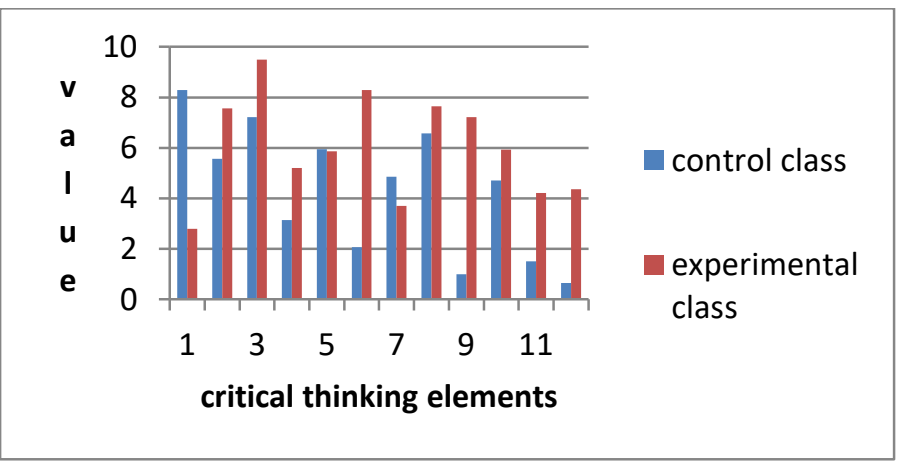

Fig. 1. Results of critical thinking skills test experimental class and control class

\section{Discussion}

Instructional design based on the model of the A-CAR oriented to the needs of students can improve curiosity of learning. Students learn without pressure, they discuss, and internet access. Students have learned the habit of critical thinking pattern. Results of higher critical thinking skills in experimental class, because they have learned that is synchronized in learning. This suggests that the critical thinking skills can be taught (Torrance, 2000 in Yayinwang, 2012; Jensen, 2011).

Improving the ability of critical thinking can occur because the learning consequences on learning activities. Learning synchronized with teaching materials as a whole learning activities. Contains teaching materials about the series of lectures arranged in a sequence, with systematic presentation (Herman, 2001) in accordance with the plan of the course of the semester. Students can design their learning activities in accordance with the order of the plan of lectures, so that students become ready to learn. Illustrations or images on any topic of teaching material has been building knowledge, and help become critical thinkers (Boyles, 2014).

Learning leads to the formation of critical thinking, the mind (brain) is based on the theory of learning (Schunk, 2012), the theory of cognition and its application (Reed, 2011), cognitive psychology (Solso, 2008), and learning-based brain (Caine and Caine, 1990; Jensen, 2011). The indication lies in responsive action in the form of a question (Browne, 2012). Students may find themselves clarity of the concept using his mind, a link to the internet for the development of knowledge and reasoning. Students use his reason to analyze, synthesize, analogical, and critical thinking, as well as the ability of metaphysics (Sadulloh, 2011), or metacognitive (Solso, 2008) to explore the logic.

Critical thinking is generated from the education, training, and practicum (Snyder and Snyder, 2008), as well as an increase in capacity. Critical thinking as a source of power that is expressed on a variety of experiences, situations, and events (Emanuel et al. 2012) The ability of critical thinking of students became an important goal of education (Bahr, 2010) set out in the curriculum, which is producing quality graduates and competitive high.

\section{CONCLUSIONS AND SUGGESTIONS}

A-CAR model study should be carried out continuously to establish patterns of thinking student. A-CAR model necessary teaching materials are also oriented companion of brain-based learning theory

\section{REFERENCES}

[1] Arend, Bridget. 2009. Encouraging Critical Thinking in Online Threaded Discussions. The Journal of Educators Online, Volume 6, Number 1, January 2009. University of Denver.

[2] Arslan, Ramazan; Gulveren, Hakan; Aydin, Erhan. 2015. A Research on Critical Thinking Tendencies and Factors that Affect Critical Thinking of Higher Education Students. Proquest.

[3] Bahr, Nan. 2010. Thinking Critically about Critical Thinking in Higher Education. International Journal for the Scholarship of Teaching and Learning. (Online), Volume 4, Number 2. (http://digitalcommons.georgiasouthern.edu/cgi/viewcontent.cgi ?article $=1229 \&$ context=ij-sotl). Access 23 December 2015 
[4] Boyles, Nancy. 2014. Close Reading without Tears. Educational Leadership. (Online), (http://www.e-resources.pnri.go.id/). Access 19 August 2015.

[5] Browne, Neil and Keeley, Stuart. 2012. Pemikiran Kritis:Panduan Untuk Mengajukan dan Menjawab Pertanyaan Kritis. Indonesian Language Edition. Jakarta:Indeks.

[6] Caine, Renate Numela; Caine, Geoffrey. 1990. Understanding a Brain Based Approach to Learning and Teaching. (Online), (http://www.ascd.org/ASCD/pdf/journals/ed_lead/el_199010_ca ine.pdf). Access 27 June 2012.

[7] Clemons, Stephanie A. 2004. Brain Based Learning: Possible Implication for Online Instruction. (Online),(https://www.middlesex.mass.edu/ace/downloads/sept0 5bb.pdf). Access 12 June 2012.

[8] Duman, Bilal. 2006. The effect of brain-based instruction to improve on students' academic achievement in social studies instruction. Mugla Univeristy Faculty of Education Department of Educational Science. (Online), (http://www.ineer.org/Events/ ICEE2006/papers/3380.pdf.) Access 27 June 2012.

[9] Emanuel, Richard C.; Siu Challons-Lipton. 2012. Helping Students Transition to Critical and Creative Thinking at the Intersection of Communication and Art. International Journal of Humanities and Social Science. (Online), Vol. 2 No. 11; June 2012.(http://www.ijhssnet.com/journals/Vol_2_No_11_June_20 12/1.pdf ). Access 23 December 2015

[10] Fisher, Alec. 2001. Critical Thinking an Introduction. Cambridge University Press.

[11] Ghraibeh, Ahmad Mohamed Al. 2012. Brain Based Learning and Its Relation with Multiple Intelligences. International Journal of Psychological Studies. Vol. 4, No. 1; March 2012. College of Education, Department of Psychology. King Saud University. (Online), (http://www.ccsenet.org/ijps). Access 27 June 2012.

[12] Gross, Richard. 2012. Psikologi: Ilmu Jiwa dan Perilaku, $6^{\text {th }}$ Edition. Indonesian Language Edition. Yogyakarta: Pustaka Pelajar.

[13] Herman, Els. 2001. Bahan Ajar yang Bertopik dan Bertingkat Kesulitan Runtut. Paper. Presented in International Conference Indonesian Language Teaching for Foreign Narrator (KIPBIPA) IV, 1-3 October 2001. Denpasar. Bali.

[14] Huang, Kuo Hung; Hung, Kai-Chi; Cheng, Ching-Ching. 2012. Enhancing Interactivity in Geography Class: Fostering Critical Thinking Skills through Technology.Journal. Problems of education in the 21st century. Volume 50, 2012.

[15] Jensen, Eric. 2011. Pemelajaran Berbasis Otak. Jakarta: Indeks.

[16] Kalelioğlu, F., \& Gülbahar, Y. (2014). The Effect of Instructional Techniques on Critical Thinking and Critical Thinking Dispositions in Online Discussion. Journal. Educational Technology \& Society, 17 (1), 248-258.

[17] Kiedinger, Rhonda. 2011. Brain-based Learning and its Effects on Reading Outcome in Elementary Aged Students. University of Wisconsin-Stout.

[18] Klinek, Shelly R. 2009. Brain Based Learning: Knowledge, Beliefs, and practices of College of Education Faculty in the Pennsylvania State System of Higher Education. Indiana University of Pennsylvania. (Online), (http://dspace.iup.edu/ handle/2069/150) . Access 27 June 2012

[19] Marrapodi, Jean. 2003. Critical Thinking and Creativity An Overview And Comparison Of The Theories. Paper. Presented in Partial Fulfillment Of the Requirements of ED7590 Critical Thinking and Adult Education December 2003.

[20] Nuangchalerm, Prasart, and Charnsirirattana, Duangkamon. 2010. A Delphi Study on Brain-based Instructional Model in Science. Canadian Social science. (Online), Vol. 6, No. 4, 2010, pp. 141-146. ISSN 1712-8056. (http://www.cscanada.net and http://www.cscanada.org). Access 6 August 2012.

[21] Ozden, Muhammet. 2008. The Effects of Brain-Based Learning on Academic Achievement and Retention of Knowledge in Science Course. (Online), (http://ejse.southwestern.edu/article/view/7763/5530) Access 2 October 2012.

[22] Paul, Richard and Elder, Linda. 2007. The Thinkers Guide to The Nature and Functions of Critical and Creative Thinking. The Foundation of Critical Thnking Press. (Online), (www.criticalthinking.org). Access 29 April 2013

[23] Pennington, Eva P. 2010. Brain-Based Learning Theory: The Incorporation Of Movement To Increase The Learning Of Grammar By High School Students. Dissertation. The Faculty of the School of Education Liberty University. (Online), (http://digitalcommons.liberty.edu/cgi/viewcontent.cgi?article= 1040\&context=doctoral). Access 27 June 2012.

[24] Pinel, John, P.J. 2009. Biopsikologi, $7^{\text {th }}$ Edition. Indonesian Language Edition. Pustaka Pelajar: Yogyakarta.

[25] Reed, Stephen K. 2011. Kognisi Teori dan Aplikasi. $7^{\text {th }}$ Edition. Indonesian Language Edition. Jakarta: Salemba Humanika.

[26] Sadulloh, Uyoh. 2011. Pengantar Filsafat Pendidikan. Bandung: Alfabeta.

[27] Saleh, Salmiza. 2011. The Effectiveness Of The Brain Based Teaching Approach In Dealing With Problems Of Form Four Students' Conceptual Understanding Of Newtonian Physics. School of Educational Studies Universiti Sains Malaysia 11800 USM Pulau Pinang. Journal of Educators and Education, (Online), Vol. 26, No. 1, 91-106, 2011. (http://www.tandfonline.com/doi/abs/10.1080/03055698.2011. 570004). Access 27 June 2012.

[28] Schunk, Dale H. 2012. Learning Theories An Education Perspective. $6^{\text {th }}$ Edition. Indonesian Language Edition. Yogyakarta: Pustaka Pelajar.

[29] Seesom, Chaweewan. 2012. The Effect of Brain-based Learning on Physical Education Students' Scientific Mind. The International Journal of Science, Mathematics and Technology Learning. (Online), Volume 19, Issue 4, pp.67-77. Srinakharinwirot University Bangkok, Thailand. (http://ijlsmtl.cgpublisher.com/product/pub.266/prod.43)Access 15 January 2013.

[30] Snyder, Lisa Gueldenzoph; Snyder, Mark J. 2008. Teaching Critical Thinking and Problem Solving Skills. The Delta Pi Epsilon Journal. (Online), Volume 1 No. 2, Spring/Summer, 2008.(http://reforma.fen.uchile.cl/Papers/Teaching\%20Critical $\% 20$ Thinking\%20Skills\%20and\%20problem\%20solving\%20 skills\%20-\%20Gueldenzoph,\%20Snyder.pdf). Access 23 December 2015.

[31] Sousa, David A. 2012. Bagaimana Otak Belajar. $4^{\text {th }}$ Edition. Jakarta: Indeks.

[32] Solso, Robert L; Maclin, Otto H; Maclin, M. Kimberly. 2008. Psikologi Kognitif. $8^{\text {th }}$ Edition. Jakarta: Erlangga.

[33] Tompkins, Abreena W. 2007. Brain-Based Learning Theory: An Online Course Design Model. Dissertation. Faculty of the School of Education Liberty University. (Online), 
(http://digitalcommons.liberty.edu/cgi/viewcontent.cgi?article= 1040\&context=doctoral). Access 27 June 2012.

[34] Yayin Wang, Amber. 2012. Contexts of Creative Thinking: A Comparison on Creative Performance of Student Teachers in Taiwan and the United States. Journal of International and Cross-Cultural studies. (Online), Volume 2, Issue 1, 2011. ISSN 1948-5786. (http://www.scientificjournals.org/ Journals2011/articles/1490.pdf), Access 23 December 2015. 